\title{
Nitidine chloride inhibits proliferation, induces apoptosis via the Akt pathway and exhibits a synergistic effect with doxorubicin in ovarian cancer cells
}

\author{
FENG DING ${ }^{1}$, TIANFENG LIU ${ }^{1}$, NINA YU ${ }^{1}$, SHIHONG LI ${ }^{1}$, XIAOFEI ZHANG ${ }^{1}$, GUANGHONG ZHENG ${ }^{1}$, \\ CHUNMING $\mathrm{LV}^{2}$, KAI MOU ${ }^{2}$, JIA XU ${ }^{2}, \mathrm{BO} \mathrm{LI}^{3}$, SURONG WANG ${ }^{1}$ and HAIBO SONG ${ }^{2}$ \\ ${ }^{1}$ Department of Gynecology and Obsterics, Linyi People's Hospital, Linyi, Shandong 276000; \\ ${ }^{2}$ Prenatal Diagnosis Center, Zibo Maternal and Child Health Hospital, Zibo, Shandong 255000; \\ ${ }^{3}$ Department of Cardiology, Central Hospital of Zibo, Zibo, Shandong 255036, P.R. China
}

Received August 2, 2015; Accepted July 4, 2016

DOI: $10.3892 / \mathrm{mmr} .2016 .5577$

\begin{abstract}
Nitidine chloride (NC) exhibits anti-tumor properties in various types of tumor. However, to the best of our knowledge there is no previous evidence of $\mathrm{NC}$ involvement in the apoptosis or proliferation of ovarian cancer cells and the underlying molecular mechanisms. The present study aimed to investigate the influence of $\mathrm{NC}$ on the viability and apoptosis of ovarian cancer cells and the synergistic effect $\mathrm{NC}$ and doxorubicin (DOX) may have on ovarian cancer cells. The viability and proliferation of ovarian cancer cells were examined using a methyl thiazolyl tetrazolium assay and ${ }^{3} \mathrm{H}$-thymidine incorporation assay. The apoptotic rate of ovarian cancer cells was detected by flow cytometry. The expression of apoptosis-associated proteins and Akt serine/threonine kinase 1 (Akt) were determined by western blot analysis following NC treatment. The inhibitory effect of $\mathrm{NC}$ on the proliferation of ovarian cancer cells was demonstrated in a time and dose-dependent manner. The pro-apoptotic effect of $\mathrm{NC}$ on ovarian cancer cells was also observed. It was determined that NC significantly downregulated the protein expression levels of B-cell CLL/lymphoma 2 (Bcl-2) and upregulated the expression of Bcl-2-associated X protein, p53, caspase-3 and -9. NC suppressed Akt phosphorylation. Additionally, the present study demonstrated that the effect of NC on the proliferation and apoptosis of
\end{abstract}

Correspondence to: Dr Haibo Song, Prenatal Diagnosis Center, Zibo Maternal and Child Health Hospital, 12 Xing Yuan Dong Road, Zibo, Shandong 255000, P.R. China

E-mail: songhb88241@163.com

Dr Surong Wang, Department of Gynecology and Obsterics, Linyi People's Hospital, 27 Jie Fang Dong Road, Linyi, Shandong 276000, P.R. China

E-mail: surongwangsubmit@163.com

Key words: nitidine chloride, proliferation, apoptosis, ovarian cancer cell, Akt ovarian cancer cells was Akt-dependent by using the phosphatidylinositol-4,5-bisphosphate 3-kinase/Akt signaling pathway inhibitor, LY294002. NC exhibited a synergistic inhibitory effect on the viability of ovarian cancer cells when combined with DOX. The current study demonstrated that $\mathrm{NC}$ inhibited the proliferation and induced the apoptosis of ovarian cancer cells via the Akt signaling pathway and highlighted its potential clinical application for the treatment of ovarian cancer.

\section{Introduction}

Ovarian cancer is a lethal gynecological malignancy and the fifth leading cause of cancer-associated mortality worldwide. In 2013 , there were $>2$ million novel cases of ovarian cancer and 1 million mortalities worldwide (1-3). Chemotherapy following surgical resection is the current primary treatment for localized ovarian cancer. Progress has been made in early diagnosis of patients; however, treatment options for the majority of patients with advanced stage ovarian cancer remain limited. Particularly, resistance to chemotherapeutical drugs often leads to poor prognosis (4-6). Therefore, it is important to investigate the potential molecular mechanisms underlying the pathogenesis of ovarian cancer, and to identify novel therapeutic agents and combination regimens in order to improve the treatment and prognosis of patients with ovarian cancer.

Nitidine chloride (NC) (Fig. 1A) is isolated from the root of Zanthoxylum nitidum (Roxb). Numerous pharmacological properties of $\mathrm{NC}$ have been previously reported, including anti-oxidant, anti-inflammatory, anti-fungal, analgesic and anti-human immunodeficiency virus functions $(7,8)$. Previous studies have determined that $\mathrm{NC}$ exhibits anti-tumor activity in several types of cancer. Additionally, NC inhibits cell proliferation and induces apoptosis in renal cancer, gastric cancer, breast cancer and hepatocellular carcinoma (9-12). $\mathrm{NC}$ was also capable of suppressing the invasion and metastasis of renal cancer via the Akt serine/threonine kinase 1 (Akt) pathway, and breast cancer by inhibiting the SRC proto-oncogene, non-receptor tyrosine kinase/focal adhesion 
kinase-associated signaling pathway $(13,14)$. However, to the best of our knowledge, no evidence has previously reported whether NC exerts any effect on ovarian cancer proliferation, apoptosis and its underlying mechanisms. NC may be successful in treating ovarian cancer; however, the synergistic effect of $\mathrm{NC}$ and other therapeutic agents requires further investigation.

The present study investigated the effects of NC on ovarian cancer cell proliferation and apoptosis. It was also determined that the Akt pathway is important for NC-induced apoptosis. Additionally, the synergistic effect of $\mathrm{NC}$ with doxorubicin (DOX) on ovarian cancer cells was evaluated.

\section{Materials and methods}

Cell lines and reagents. The A2780 human ovarian cancer cell line was purchased from the American Type Culture Collection (Manassas, VA, USA) and cultured in RPMI-1640 (Invitrogen; Thermo Fisher Scientific, Inc., Waltham, MA, USA) containing $10 \%$ fetal bovine serum (FBS; Invitrogen; Thermo Fisher Scientific, Inc.), $100 \mathrm{U} / \mathrm{ml}$ penicillin, and $100 \mu \mathrm{g} / \mathrm{ml}$ streptomycin in $5 \% \mathrm{CO}_{2}$ at $37^{\circ} \mathrm{C}$. Rabbit anti-Akt (cat. no. 4685), phosphorylated-Akt (cat. no. 4058), B-cell CLL/lymphoma 2 (Bcl-2; cat. no. 2870), Bcl-2-associated X protein (Bax; cat. no. 502), p53 (cat. no. 2527), caspase-3 (cat.no.9665) and -9 (cat. no. 9502) antibodies were purchased from Cell Signaling Technology, Inc. (Danvers, MA, USA). NC was purchased from Tauto Biotech Co., Ltd. (Shanghai, China) and dissolved in dimethyl sulfoxide (DMSO). LY294002, a selective phosphatidylinositol-4,5-bisphosphate 3-kinase (PI3K) Akt inhibitor, was purchased from Sigma-Aldrich (St. Louis, MO, USA). Annexin V-fluorescein isothiocyanate (FITC)/propidium iodide (PI) apoptosis detection kit was purchased from BD Biosciences (Franklin Lakes, NJ, USA).

Methyl thiazolyl tetrazolium (MTT) assay of cell viability and proliferation. Cell viability and proliferation were detected by using MTT assay. A2780 cells in $100 \mu \mathrm{l}$ RPMI-1640 were seeded at a density of $5.0 \times 10^{3}$ cells/well in 96-well plates. Following treatment with $\mathrm{NC}(0,2.5,5,10,20$ or $50 \mu \mathrm{M})$ and/or DOX $(0,0.25,0.5,1,2,5 \mu \mathrm{M}$; Aladdin Reagents Co., Ltd., Shanghai, China) for different time-points (24, 48 or $72 \mathrm{~h}), 20 \mu \mathrm{l}$ MTT $(5 \mathrm{mg} / \mathrm{ml})$ was added to each well. Subsequently, the cells were incubated for $4 \mathrm{~h}$, then $100 \mu \mathrm{l}$ DMSO was added to each well for another $15 \mathrm{~min}$. Finally, the absorbance values were detected using a microplate luminometer (Bio-Rad Laboratories, Inc., Hercules, CA, USA) at $490 \mathrm{~nm}$.

${ }^{3} \mathrm{H}$-thymidine incorporation assay. A2780 cells were cultured in RPMI-1640 with $10 \%$ FBS at $50 \%$ confluence. Next, the A2780 cells were cultured in serum-free RPMI-1640 for $24 \mathrm{~h}$ and treated with $\mathrm{NC}$ at different concentrations $(0,2.5,5,10,20 \mu \mathrm{M})$ for $40 \mathrm{~h} .{ }^{3} \mathrm{H}$-thymidine (final concentration $1 \mathrm{uCi} / \mathrm{ml}$ ) was added to the media during the last $24 \mathrm{~h}$ of culturing. The cells were then washed with ice-cold phosphate-buffered saline (PBS), and precipitated with ice-cold 5\% trichloroacetic acid (TCA; Sigma-Aldrich) for $4 \mathrm{~h}$. The cells were washed with ice-cold 5\% TCA twice, followed by washed with ice-cold PBS. Subsequently, the cells were lysed using $200 \mu 10.5 \mathrm{M} \mathrm{NaOH}$ for $30 \mathrm{~min}$ at $37^{\circ} \mathrm{C}$. DNA synthesis was determined by ${ }^{3} \mathrm{H}$-thymidine uptake using a liquid scintillation counter (LS-6500; Beckman Coulter, Inc., Brea, CA, USA).

Western blot analysis. Total cell protein concentrations were detected by using the Pierce bicinchoninic acid protein assay kit (Thermo Fisher Scientific, Inc.). Equal quantity of protein from cell lysates $(10 \mu \mathrm{g})$ were loaded on $12 \%$ sodium dodecyl sulfate-polyacrylamide gel electrophoresis gels. Following electrophoresis, proteins were transferred to polyvinylidene fluoride membranes (EMD Millipore, Billerica, MA, USA), blocked with $5 \%$ fat-free milk at room temperature for $1 \mathrm{~h}$, and incubated with the aforementioned primary antibodies overnight at $4^{\circ} \mathrm{C}$. The membranes were subsequently washed with Tris-buffered saline Tween-20 and incubated with horseradish peroxidase-conjugated goat anti-rabbit secondary antibodies (cat. no. ZDR-5306; OriGene Technologies, Inc., Shanghai, China) for $1 \mathrm{~h}$ at room temperature. Immune complexes were detected with enhanced chemiluminescence reagents (EMD Millipore), and the blots were quantified by densitometric analysis using the AlphaImager IS 2200.

Apoptosis analysis by Annexin V/PI assay. Apoptosis of A2780 cells was detected by using the Annexin V-FITC/PI assay. A2780 cells were seeded into 6-well plates at a density of $1.0 \times 10^{6}$ cells/well. Following NC treatment $(0,10,20 \mu \mathrm{M})$ for $24 \mathrm{~h}$ the A2780 cells were harvested, washed and resuspended in PBS. Apoptotic cells were determined using an Annexin V-FITC apoptosis detection kit according to the manufacturer's protocol. Briefly, the A2780 cells were washed and then incubated for $15 \mathrm{~min}$ at room temperature in the dark in $200 \mu \mathrm{l} 1 \mathrm{X}$ binding buffer containing $5 \mu \mathrm{l}$ Annexin V-FITC and $10 \mu \mathrm{l}$ PI. The apoptotic rate was detected by the BD Accuri C6 flow cytometer (BD Biosciences) and processed using FlowJo software (version 7.0; Tree Star, Inc., Ashland, OR, USA).

Statistical analysis. Data are expressed as the mean \pm standard deviation. All of the experiments were repeated at least three times. Comparisons among values for all groups were performed using a one-way analysis of variance with Dunnett's test for comparison of multiple groups. $\mathrm{P}<0.05$ was considered to indicate a statistically significant difference.

\section{Results}

$N C$ inhibits the proliferation of ovarian cancer cells. An MTT assay was performed to determine the effect of $\mathrm{NC}$ on ovarian cancer cell proliferation. As presented in Fig. 1B, NC significantly reduced the proliferation of ovarian cancer cells in a time- and dose-dependent manner compared with the control group $(\mathrm{P}<0.01)$. To verify the aforementioned findings, a ${ }^{3} \mathrm{H}$-thymidine incorporation assay was used to determine the importance of $\mathrm{NC}$ on the proliferation of ovarian cancer cells. As presented in Fig. 1C, $\mathrm{NC}(2.5,5,10$ and $20 \mu \mathrm{M})$ significantly suppressed the proliferation of ovarian cancer cells compared with the control $(\mathrm{P}=0.038, \mathrm{P}=0.0071, \mathrm{P}=0.0062$, $\mathrm{P}=0.0050$, respectively). The 10 and $20 \mu \mathrm{M}$ NC concentrations 
A<smiles>COc1cc2cc(OC)c3c4cc5c(cc4ccc3c2cc1OC)OCO5</smiles>

B

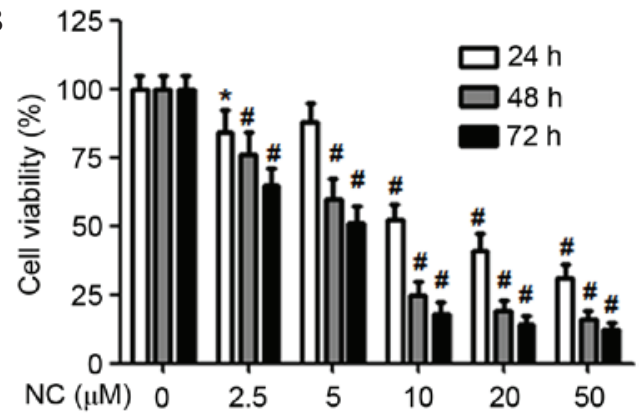

C

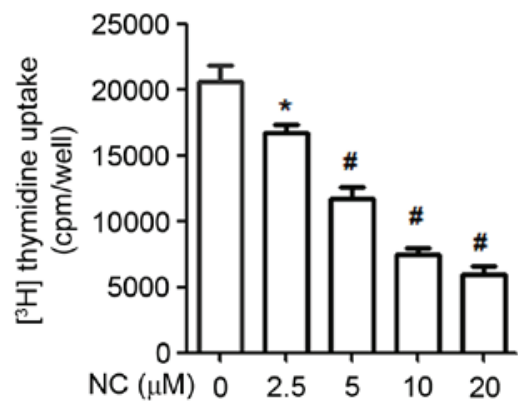

Figure 1. NC inhibited the proliferation of A2780 ovarian cancer cells. (A) Chemical structure of NC. (B) NC treatment for different time periods ( 24,48 and $72 \mathrm{~h}$ ) and different concentration gradients $(0,2.5,5,10,20$ and $50 \mu \mathrm{M})$, methyl thiazolyl tetrazolium assay was used to determine the viability of A2780 cells. (C) Following $40 \mathrm{~h}$ treatment with $\mathrm{NC}$ at different concentrations $(0,2.5,5,10$ and $20 \mu \mathrm{M}),{ }^{3} \mathrm{H}$-thymidine incorporation assay was used to detect the proliferation of A2780 cells. ${ }^{*} \mathrm{P}<0.05,{ }^{\#} \mathrm{P}<0.01$ vs. control group. Data are presented as the mean \pm standard deviation of three independent experiments. NC, nitidine chloride.

A
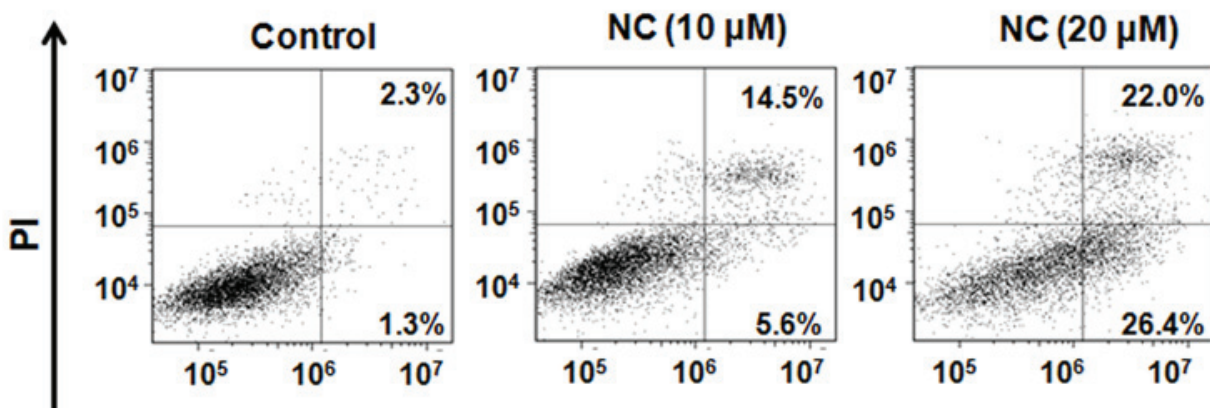

Annexin V

B

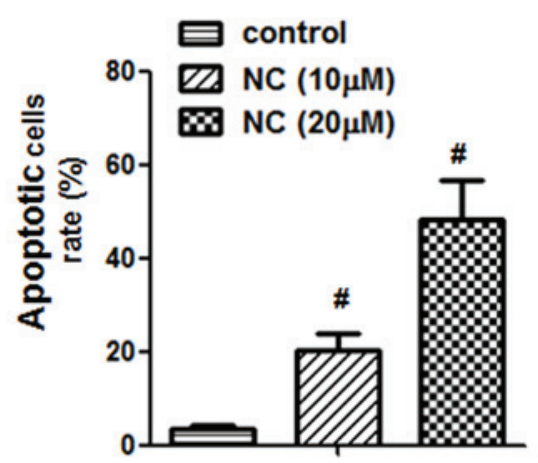

Figure 2. NC induced dose-dependent apoptosis in A2780 ovarian cancer cells. (A) A2780 cells were treated with NC $(0,10$ and $20 \mu \mathrm{M})$ for $24 \mathrm{~h}$ and double-stained with Annexin V and PI. Then the A2780 cells were analyzed with a flow cytometer. (B) The bar graph represents the mean \pm standard deviation of three independent experiments. ${ }^{\#} \mathrm{P}<0.01$ vs. the control group. NC, nitidine chloride; PI, propidium iodide. 

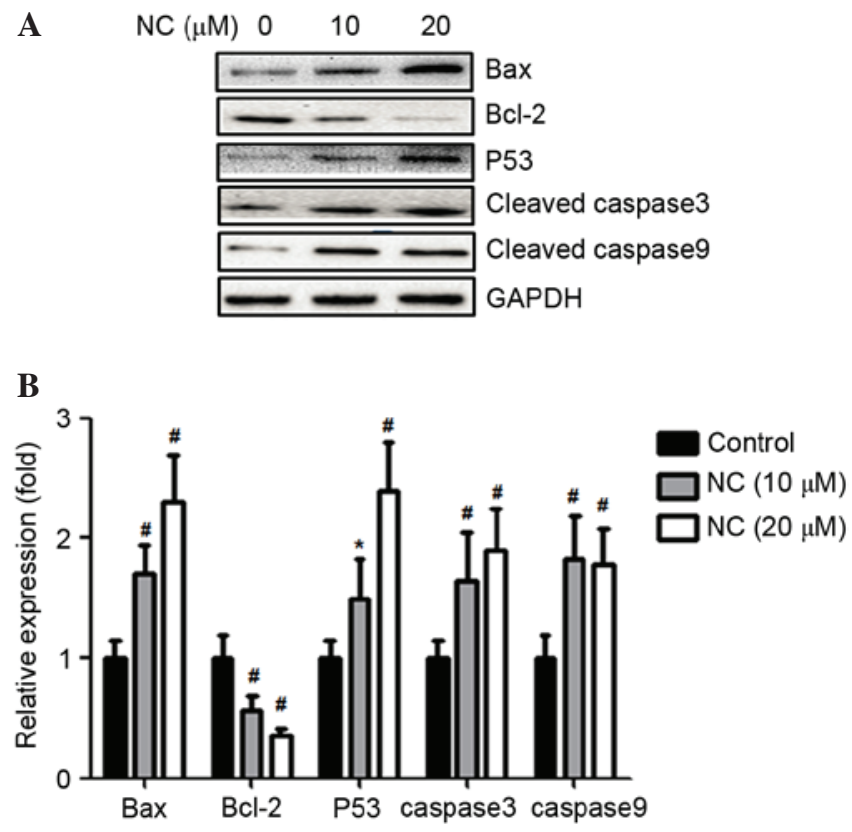

Figure 3. NC reduced the expression of Bcl-2 and increased the expression of Bax, Bcl-2, p53, caspase-3 and -9 in A2780 ovarian cancer cells. (A) A2780 cells were treated with $\mathrm{NC}(0,10$ and $20 \mu \mathrm{M})$ for $24 \mathrm{~h}$. The expression levels of Bax, Bcl-2, p53, cleaved caspase-3 and -9 in cell lysates were detected using western blot analysis. (B) Statistical analysis of the western blot results ${ }^{*} \mathrm{P}<0.05,{ }^{\text {"}} \mathrm{P}<0.01$ vs. control group. Data are presented as the mean \pm standard deviation from three independent experiments. $\mathrm{NC}$, nitidine chloride; Bax, Bcl-2-associated X protein; Bcl-2, B-cell CLL/lymphoma 2.

were selected for the subsequent experiments. These data suggested that $\mathrm{NC}$ effectively suppressed the proliferation of ovarian cancer cells.

$N C$ induces apoptosis in ovarian cancer cells. To confirm that the inhibitory effect of $\mathrm{NC}$ on the proliferation of A2780 ovarian cancer cells was due to the direct effect on apoptosis, the $\mathrm{A} 2780$ cells were treated with $\mathrm{NC}(0,10$ and $20 \mu \mathrm{M})$ for $24 \mathrm{~h}$. As presented in Fig. 2 it was determined that 10 and $20 \mu \mathrm{M} \mathrm{NC}$ significantly promoted the apoptosis of ovarian cancer cells compared with the control group $(\mathrm{P}=0.0035$ and $\mathrm{P}=0.0010$, respectively). The apoptotic rate of ovarian cancer cells increased from $2.3 \pm 1.3$ (control) to $14.5 \pm 5.6$ and $22.0 \pm 26.4 \%$ following treatment with 10 and $20 \mu \mathrm{M}$, respectively, for $24 \mathrm{~h}$. These findings demonstrated the anti-tumor effect of $\mathrm{NC}$ on ovarian cancer cells.

$N C$ induces the apoptosis of ovarian cancer cells via altered expression levels of apoptosis-associated proteins. In order to determine the underlying mechanism of ovarian cancer cell apoptosis induced by NC, the protein expression levels of Bax, Bcl-2, p53, caspase-3 and -9 were determined. Western blot analysis demonstrated that, following treatment with NC (10 and $20 \mu \mathrm{M})$, the expression levels of pro-apoptotic protein $\mathrm{Bax}$ were significantly upregulated $(\mathrm{P}=0.0074$ and $\mathrm{P}=0.0058$, respectively; Fig. 3) and the expression levels of the anti-apoptotic protein, Bcl-2 were significantly downregulated compared with the control group $(\mathrm{P}=0.0062$ and $\mathrm{P}=0.0044$, respectively; Fig. 3). Simultaneously, the protein expression levels of $\mathrm{p} 53(10 \mu \mathrm{M} \mathrm{NC}, \mathrm{P}=0.031 ; 20 \mu \mathrm{M} \mathrm{NC}, \mathrm{P}=0.0040)$, caspase-3 $(10 \mu \mathrm{M} \mathrm{NC}, \mathrm{P}=0.0054 ; 20 \mu \mathrm{M} \mathrm{NC}, \mathrm{P}=0.0057)$
A

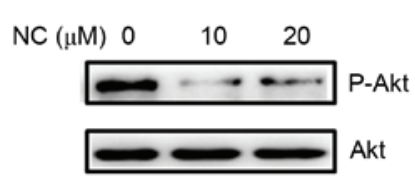

B

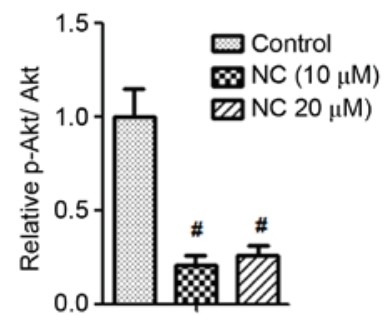

C

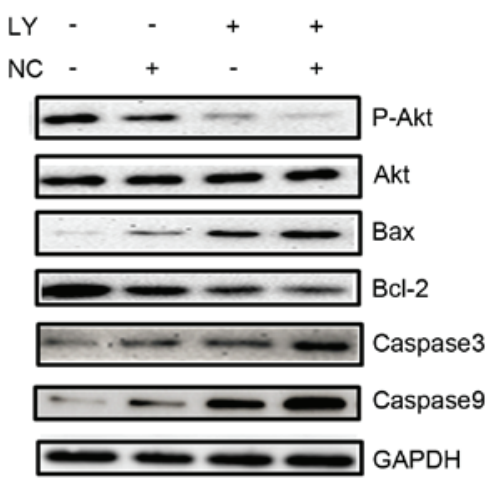

D

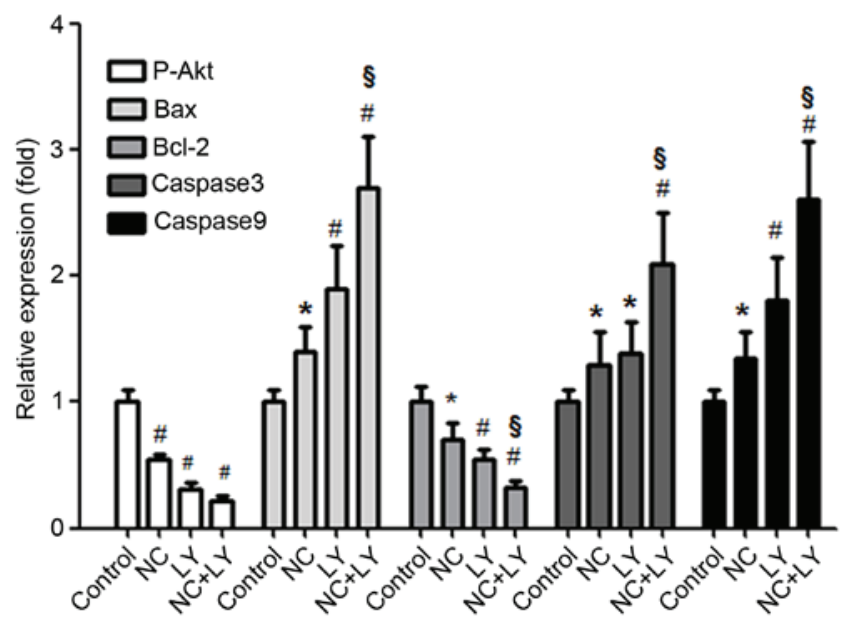

Figure 4. NC inhibited Akt phosphorylation and the pro-apoptotic effect on A2780 cells was Akt-dependent. (A) A2780 cells were treated with $\mathrm{NC}(0,10$ and $20 \mu \mathrm{M})$ for $24 \mathrm{~h}$ and the levels of $\mathrm{p}$-Akt, Akt were analyzed by western blotting. (B) Statistical analysis of the western blotting results. ${ }^{~} \mathrm{P}<0.01$ vs. control group. (C) A2780 cells were pretreated with the Akt inhibitor LY $(50 \mu \mathrm{M})$ for 30 min followed by incubation with or without NC $(20 \mu \mathrm{M})$ for $24 \mathrm{~h}$. The expression levels of p-Akt, Akt, Bax, Bcl-2, caspase-3 and -9 were detected by western blotting with GAPDH as an internal control. (D) Statistical analysis of the western blotting results. ${ }^{*} \mathrm{P}<0.05,{ }^{\#} \mathrm{P}<0.01$ vs. control group, ${ }^{\circledR} \mathrm{P}<0.01$ vs. $\mathrm{NC}$-treated group. Data are presented as the mean \pm standard deviation from three independent experiments. p-Akt, phosphorylated-AKT serine/threonine kinase 1; NC, nitidine chloride; Bax, Bcl-2-associated X protein; Bcl-2, B-cell CLL/lymphoma 2; LY, LY294002.

and $-9(10 \mu \mathrm{M} \mathrm{NC}, \mathrm{P}=0.0055 ; 20 \mu \mathrm{M} \mathrm{NC}, \mathrm{P}=0.0054)$ were also significantly upregulated compared with the control group (Fig. 3). 
A

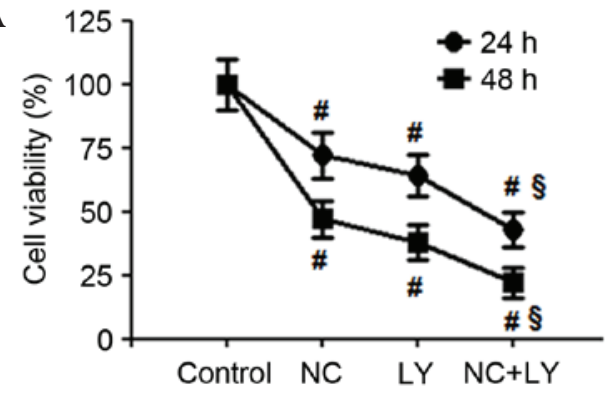

B

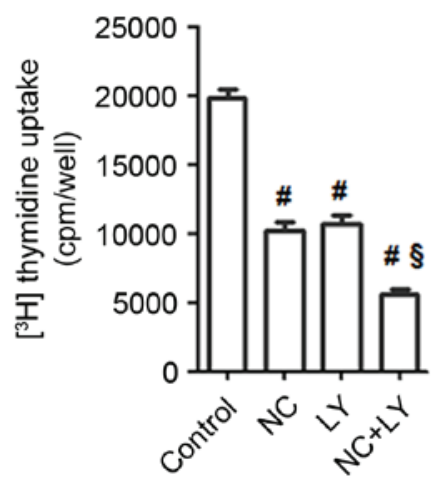

Figure 5. NC inhibited the proliferation of A2780 cells. (A) A2780 cells were pretreated with LY $(50 \mu \mathrm{M})$ for 30 min followed by incubation with or without $\mathrm{NC}(20 \mu \mathrm{M})$ for 24 and $48 \mathrm{~h}$, cell viability was determined by methyl thiazolyl tetrazolium assay. (B) A2780 cells were pretreated by using $\mathrm{LY}(50 \mu \mathrm{M})$ for $30 \mathrm{~min}$ followed by incubation with or without $\mathrm{NC}(20 \mu \mathrm{M})$ for $40 \mathrm{~h}$, then cell proliferation was determined by ${ }^{3} \mathrm{H}$-thymidine incorporation assay. Data are presented as the mean \pm standard deviation from three independent experiments. ${ }^{\#} \mathrm{P}<0.01$ vs. control group, ${ }^{\S} \mathrm{P}<0.01$ vs. NC-treated group. NC, nitidine chloride; LY, LY294002.

NC inhibits Akt phosphorylation in ovarian cancer cells. The Akt signaling pathway is important for tumor progression. To determine the molecular mechanism involved in the effect of $\mathrm{NC}$ on the proliferation and apoptosis of ovarian cancer cells, the Akt signaling pathway was examined. As presented in Fig. 4A and $\mathrm{B}$, Akt phosphorylation was significantly downregulated by treatment with $\mathrm{NC}(10$ and $20 \mu \mathrm{M} ; \mathrm{P}=0.0041$ and $\mathrm{P}=0.0045$, respectively) for $24 \mathrm{~h}$, compared with the control group $(\mathrm{P}<0.01)$. This indicated that the Akt signaling pathway may be involved in the viability and apoptosis of ovarian cancer cells.

Suppression of the Akt signaling pathway enhanced the pro-apoptotic and anti-proliferative effect of NC on ovarian cancer cells. LY294002, a PI3K inhibitor, was used to stop Akt phosphorylation. As presented in Fig. 4C and D, the inhibition of Akt phosphorylation with LY294002 significantly enhanced the NC-induced downregulation of the $\mathrm{Bcl}-2$ expression levels compared with $\mathrm{NC}$ treatment only $(\mathrm{P}=0.0061)$, whereas the expression levels of Bax, caspase-3 and -9 were significantly upregulated by LY294002 + NC treatment compared with $20 \mu \mathrm{M}$ NC treatment alone $(\mathrm{P}=0.0033, \mathrm{P}=0.0041$ and $\mathrm{P}=0.0052)$. These findings indicated that NC-induced apoptosis may be PI3K/Akt-dependent. Furthermore, the effect of NC on the proliferation of ovarian cancer cells and the PI3K/Akt signaling pathway was determined using an MTT assay (Fig. 5A) and ${ }^{3} \mathrm{H}$-thymidine incorporation assay (Fig. 5B). As presented in Fig. 5A, the
A

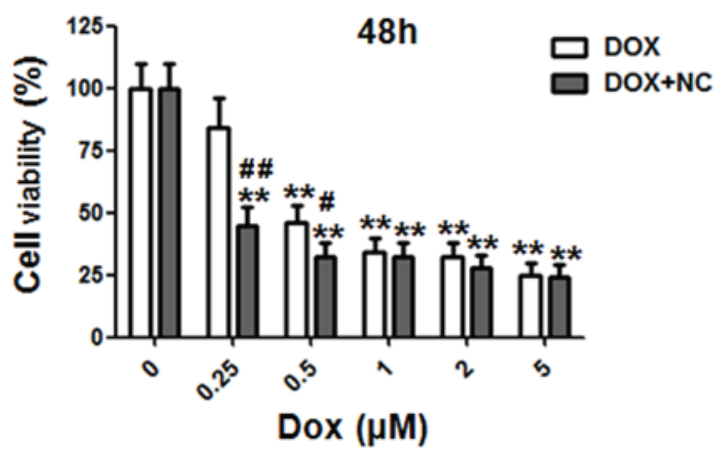

B

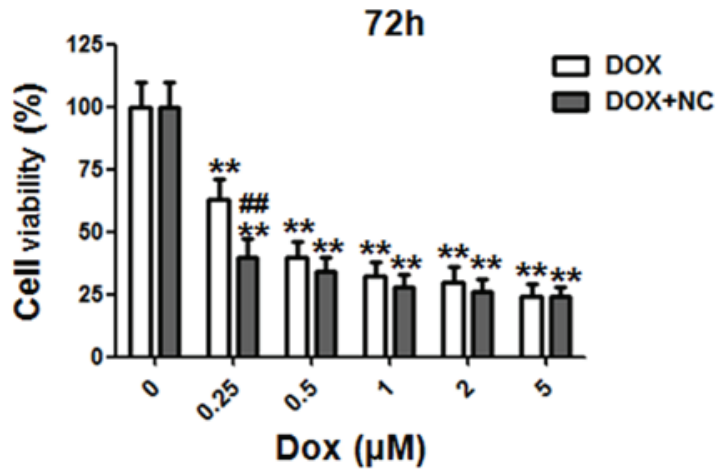

Figure 6. Synergistic effect of NC and DOX on the viability of A2780 cells. Subsequent to treatment with DOX alone $(0.25,0.5,1,2,5 \mu \mathrm{M})$ or in combination with NC (2 $\mu \mathrm{M})$ for (A) $48 \mathrm{~h}$ and (B) $72 \mathrm{~h}$, A2780 cell proliferation was detected using an methyl thiazolyl tetrazolium assay. Data are presented as the mean \pm standard deviation of three independent experiments. ${ }^{* *} \mathrm{P}<0.01$ vs. $0 \mu \mathrm{M}$ controls; ${ }^{\#} \mathrm{P}<0.05$, ${ }^{\# \#} \mathrm{P}<0.01$ vs. DOX-treated group. DOX, doxorubicin; NC, nitidine chloride.

PI3K/Akt inhibitor LY294002, significantly enhanced the NC-induced suppression of the proliferation of ovarian cancer cells compared with the control and the $\mathrm{NC}$-only treated group ( $\mathrm{P}=0.0057,24 \mathrm{~h} ; \mathrm{P}=0.0051,48$ h). As demonstrated in Fig. 5B, LY294002 enhanced ${ }^{3} \mathrm{H}$-thymidine incorporation compared with $\mathrm{NC}$ alone $(\mathrm{P}=0.0066)$. Therefore, blocking Akt activation may significantly enhance the NC-induced suppression of the proliferation of ovarian cancer cells.

NC exhibits a synergistic effect with DOX on limiting cell viability of ovarian cancer cells. A previous study on anti-tumor agents focused on limiting drug resistance of traditional chemotherapeutic agents by combining with novel anti-tumor drugs to achieve optimal curative effects (14). In order to investigate the synergistic effect of $\mathrm{NC}$ and DOX on A2780 ovarian cancer cells, the cells were treated with various doses of DOX $(0,0.25,0.5,1,2,5 \mu \mathrm{M})$ and $\mathrm{NC}(2 \mu \mathrm{M})$ for 48 and $72 \mathrm{~h}$ (Fig. 6A and B). The cell viability was examined by MTT assays. DOX alone or in combination with $\mathrm{NC}$ $(2 \mu \mathrm{M})$ inhibited the viability of ovarian cancer cells in a timeand dose-dependent manner. Notably, the viability of A2780 cells was decreased from $84.2 \pm 11.2$ to $43.5 \pm 7.1(\mathrm{P}=0.0063)$, and $45.7 \pm 6.8$ to $31.8 \pm 5.3 \%(\mathrm{P}=0.034)$, respectively, when treated with 0.25 and $0.5 \mu \mathrm{M}$ DOX, in combination with $\mathrm{NC}$ $(2 \mu \mathrm{M})$ at $48 \mathrm{~h}$. For the $72 \mathrm{~h}$ treatment, the viability of A2780 cells decreased from $55.9 \pm 9.2$ to $44.6 \pm 6.1 \%(\mathrm{P}=0.0083)$ when treated with $0.25 \mu \mathrm{M}$ DOX in combination with $\mathrm{NC}(2 \mu \mathrm{M})$. 
These findings indicated that the combination of DOX and $\mathrm{NC}$ exerted a synergistic inhibitory effect on the viability of the ovarian cancer cells.

\section{Discussion}

Uncontrolled proliferation and resistance to apoptosis of tumor cells is considered to contribute to mortality in patients with ovarian cancer $(15,16)$. Conventional chemotherapeutic agents have limited long-term application due to their side effects. Therefore, understanding the molecular mechanisms of proliferation and apoptosis, and developing effective approaches to inhibit proliferation and induce apoptosis of cancer cells are the crucial for cancer research. Therefore, investigations of the therapeutic features of natural products in tumor therapy are frequently performed $(17,18)$. As a bioactive phytochemical alkaloid extracted from Zanthoxylum nitidum (Roxb), NC exhibits multiple pharmacological effects on oxidation and inflammation $(7,8)$. Previous studies have demonstrated the capacity of $\mathrm{NC}$ to induce apoptosis and inhibit of proliferation, migration and invasion in breast, renal, hepatocellular carcinoma and gastric cancer cells (9-14). However, the effect of $\mathrm{NC}$ on ovarian cancer apoptosis and proliferation had not been fully elucidated and the molecular mechanisms were unclear. To the best of our knowledge, the current study was the first to demonstrate that $\mathrm{NC}$ may effectively suppress the viability of ovarian cancer cells and induce their apoptosis. The mechanism of proliferation inhibition by NC was due to downregulation of the Akt signaling pathway. Therefore, a novel molecular mechanism that allows $\mathrm{NC}$ to exhibit the anti-tumor activity in ovarian cancer cells was identified.

Cell apoptosis is regulated by various factors, including Bcl-2 protein family members and caspases (19). The Bcl-2 protein family members, including the anti-apoptotic proteins (Bcl-2, Bcl-2-like 1, Bcl-2-like 2 and myeloid cell leukemia 1) and pro-apoptotic proteins [Bax and Bcl-2-associated agonist of cell death (Bad)] are important for apoptosis and act via caspases $(19,20)$. Previous studies have determined that in the process of apoptosis, the release of cytochrome $\mathrm{C}$ was regulated by Bax mitochondria translocation and oligomerization, which in turn activated caspase-3 and $-9(21,22)$. Subsequently, cell apoptosis is triggered by the inhibition of $\mathrm{Bcl}-2$ and $\mathrm{Bax}$ oligomerization. Thus, Bcl-2 was understood to stabilize the mitochondrial membrane by blocking internal calcium release into the cytoplasm $(23,24)$. A previous study demonstrated that the tumor suppressor, p53, was associated with several Bcl-2 protein family members involved in cell apoptosis (25). Previous studies have determined that NC inhibited the proliferation of renal and breast cancer cells by inducing apoptosis, and regulating the expression levels of Bcl-2 and Bax $(9,12)$. The present study demonstrated that $\mathrm{NC}$ inhibited the proliferation of ovarian cancer cells and induced their apoptosis in a time- and dose-dependent manner. The expression levels of apoptosis-associated proteins (Bax and $\mathrm{Bcl}-2)$ in ovarian cancer cells, treated with $\mathrm{NC}$ were also investigated. It was determined that $\mathrm{NC}$ altered the expression level ratio of Bax to Bcl-2. Additionally, caspase-3 and -9 were activated by NC treatment, which resulted in the apoptosis of ovarian cancer cells. The current study also examined the effect of $\mathrm{NC}$ on the expression levels of p53 in ovarian cancer cells and demonstrated the upregulation of p53 in a dose-dependent manner. These results indicated that NC-induced apoptosis of ovarian cancer cells may be a result of the imbalance between $\mathrm{Bcl}-2$ and Bax expression levels, and the activation of caspase-3 and -9. Additionally, p53 was also demonstrated to be involved in NC-induced apoptosis of ovarian cancer cells.

Akt has been previously established as an important regulator of cell proliferation and survival (26). A previous study demonstrated that Akt mediated cell survival and apoptosis via its downstream targets, including Bad and caspase-9 (27). Another previous study indicated that Akt affected the regulation of Bax activity (28). The present study determined that the expression of p-Akt was decreased when cells were treated with NC. To determine whether the Akt signaling pathway was involved in NC-induced apoptosis of ovarian cancer cells and inhibited their proliferation, Akt phosphorylation was blocked by using the PI3K/Akt inhibitor,LY294002. It was demonstrated that the inhibition of Akt activity by LY294002 enhanced the apoptotic rate induced by $\mathrm{NC}$, which was determined by western blot analysis and MTT assays. These results suggested that NC-induced apoptosis of ovarian cancer cells by inhibition of Akt phosphorylation and altering the expression levels of the Bcl-2 protein family members. The PI3K/Akt inhibitor (LY294002) enhancing the apoptotic rate induced by NC also suggested that Akt was located upstream of Bcl-2 and Bax.

To reduce the resistance to therapeutic agents, combination therapy is frequently used in cancer treatment (29). The anticancer agent DOX is highly effective for the treatment multiple types of cancer. However, there are problems with side effects, including acute and chronic cardiotoxicity, and neutropenia, which significantly limit its chemotherapeutic usage (30). Thus, it is important to develop combination therapies in order to decrease the side effects of chemotherapy agents. The present study determined the synergistic effect of $\mathrm{NC}$ and DOX in ovarian cancer cells. NC exerted a synergistic inhibitory effect on the viability of ovarian cancer cells and enhanced the anti-tumor effect when administered in conjunction with a low dose of DOX. This indicates that a combination of $\mathrm{NC}$ and DOX at certain concentrations may reduce its side effects. The precise mechanisms by which NC improves chemotherapeutic efficacy require further investigation.

In conclusion, to the best of our knowledge, the present study was the first to demonstrate that NC suppressed the proliferation of ovarian cancer cells and induced their apoptosis. Additionally, the effect of $\mathrm{NC}$ was demonstrated to be mediated by the Akt signaling pathway. NC exhibited a synergistic effect with DOX in ovarian cancer cells. Therefore, it was determined that $\mathrm{NC}$ is a promising agent for ovarian cancer therapy and additional in vivo studies are required to confirm its efficacy.

\section{Acknowledgements}

The present study was supported by the Natural Science Foundation of Shandong Province (grant no. ZR2014HP005).

\section{References}

1. Siegel R, Ma J, Zou Z and Jemal A: Cancer statistics, 2014. CA Cancer J Clin 64: 9-29, 2014.

2. Jemal A, Bray F, Center MM, Ferlay J, Ward E and Forman D: Global cancer statistics. CA Cancer J Clin 61: 69-90, 2011. 
3. Cohen M, Pierredon S, Wuillemin C, Delie F and Petignat $\mathrm{P}$. Acellular fraction of ovarian cancer ascites induce apoptosis by activating JNK and inducing BRCA1, Fas and FasL expression in ovarian cancer cells. Oncoscience 1: 262-271, 2014.

4. Sun ZL, Tang YJ, Wu WG, Xing J, He YF, Xin DM, Yu YL, Yang Y and Han P: AZD1480 can inhibit the biological behavior of ovarian cancer SKOV3 cells in vitro. Asian Pac J Cancer Prev 14: 4823-4827, 2013.

5. Holschneider CH and Berek JS: Ovarian cancer: Epidemiology, biology and prognostic factors. Semin Surg Oncol 19: 3-10, 2000

6. Vaughan S, Coward JI, Bast RC Jr, Berchuck A, Berek JS, Brenton JD, Coukos G, Crum CC, Drapkin R, Etemadmoghadam D, et al: Rethinking ovarian cancer: Recommendations for improving outcomes. Nat Reviews Cancer 11: 719-725, 2011.

7. Wang Z, Jiang W, Zhang Z, Qian M and Du B: Nitidine chloride inhibits LPS-induced inflammatory cytokines production via MAPK and NFkappab pathway in raw 264.7 cells. J Ethnopharmacol 144: 145-150, 2012.

8. Del Poeta M, Chen SF, Von Hoff D, Dykstra CC, Wani MC, Manikumar G, Heitman J, Wall ME and Perfect JR: Comparison of in vitro activities of camptothecin and nitidine derivatives against fungal and cancer cells. Antimicrob Agents Chemother 43: 2862-2868, 1999.

9. Fang Z, Tang Y, Jiao W, Xing Z, Guo Z, Wang W, Xu Z and Liu Z: Nitidine chloride induces apoptosis and inhibits tumor cell proliferation via suppressing ERK signaling pathway in renal cancer. Food Chem Toxicol 66: 210-216, 2014

10. Chen J, Wang J, Lin L, He L, Wu Y, Zhang L, Yi Z, Chen Y, Pang $X$ and Liu M: Inhibition of STAT3 signaling pathway by nitidine chloride suppressed the angiogenesis and growth of human gastric cancer. Mol Cancer Ther 11: 277-287, 2012.

11. Liao J, Xu T, Zheng JX, Lin JM, Cai QY, Yu DB and Peng J: Nitidine chloride inhibits hepatocellular carcinoma cell growth in vivo through the suppression of the JAK1/STAT3 signaling pathway. Int J Mol Med 32: 79-84, 2013.

12. Sun M, Zhang N, Wang X, Cai C, Cun J, Li Y, Lv S and Yang Q: Nitidine chloride induces apoptosis, cell cycle arrest and synergistic cytotoxicity with DOX in breast cancer cells. Tumour Biol 35: 10201-10212, 2014.

13. Fang Z, Tang Y, Jiao W, Xing Z, Guo Z, Wang W, Shi B, Xu Z and Liu Z: Nitidine chloride inhibits renal cancer cell metastasis via suppressing AKT signaling pathway. Food Chem Toxicol 60: 246-251, 2013

14. Pan X, Han H, Wang L, Yang L, Li R, Li Z, Liu J, Zhao Q, Qian M, Liu M and Du B: Nitidine chloride inhibits breast cancer cells migration and invasion by suppressing c-Src/FAK associated signaling pathway. Cancer Lett 313: 181-191, 2011.

15. Adams JM and Cory S: The Bcl-2 apoptotic switch in cancer development and therapy. Oncogene 26: 1324-1337, 2007.
16. Cai Q, Lin J, Wei L, Zhang L, Wang L, Zhan Y, Zeng J, Xu W, Shen A, Hong Z and Peng J: Hedyotis diffusa willd inhibits colorectal cancer growth in vivo via inhibition of STAT3 signaling pathway. Int J Mol Sci 13: 6117-6128, 2012.

17. Surh YJ: Cancer chemoprevention with dietary phytochemicals. Nat Rev Cancer 3: 768-780, 2003.

18. Thomasset SC, Berry DP, Garcea G, Marczylo T, Steward WP and Gescher AJ: Dietary polyphenolic phytochemicals-promising cancer chemopreventive agents in humans? A review of their clinical properties. Int J Cancer 120: 451-458, 2007.

19. Zhang Y, Zhuang Z, Meng Q, Jiao Y, Xu J and Fan S: Polydatin inhibits growth of lung cancer cells by inducing apoptosis and causing cell cycle arrest. Oncology lett 7: 295-301, 2014.

20. Reed JC: Bcl-2: Prevention of apoptosis as a mechanism of drug resistance. Hematol Oncol Clin North Am 9: 451-473, 1995.

21. Antonsson B: Bax and other pro-apoptotic Bcl-2 family 'killer-proteins' and their victim the mitochondrion. Cell Tissue Res 306: 347-361, 2001.

22. Crompton M: Bax, Bid and the permeabilization of the mitochondrial outer membrane in apoptosis. Curr Opin Cell Biol 12: 414-419, 2000

23. Baffy G, Miyashita T, Williamson JR and Reed JC: Apoptosis induced by withdrawal of interleukin-3 (IL-3) from an IL-3-dependent hematopoietic cell line is associated with repartitioning of intracellular calcium and is blocked by enforced Bcl-2 oncoprotein production. J Biol Chem 268: 6511-6519, 1993.

24. Precht TA, Phelps RA, Linseman DA, Butts BD, Le SS Laessig TA, Bouchard RJ and Heidenreich KA: The permeability transition pore triggers Bax translocation to mitochondria during neuronal apoptosis. Cell Death Differ 12: 255-265, 2005.

25. Yu Q: Restoring p53-mediated apoptosis in cancer cells: New opportunities for cancer therapy. Drug Resist Updat 9: 19-25, 2006.

26. Somanath PR, Vijai J, Kichina JV, Byzova T and Kandel ES: The role of PAK-1 in activation of MAP kinase cascade and oncogenic transformation by Akt. Oncogene 28: 2365-2369, 2009.

27. Datta SR, Brunet A and Greenberg ME: Cellular survival: A play in three Akts. Genes Dev 13: 2905-2927, 1999.

28. Gardai SJ, Hildeman DA, Frankel SK, Whitlock BB, Frasch SC, Borregaard N, Marrack P, Bratton DL and Henson PM: Phosphorylation of Bax Ser184 by Akt regulates its activity and apoptosis in neutrophils. J Biol Chem 279: 21085-21095, 2004.

29. Khan KH, Blanco-Codesido M and Molife LR: Cancer therapeutics: Targeting the apoptotic pathway. Crit Rev Oncol Hematol 90: 200-219, 2014.

30. Octavia Y, Tocchetti CG, Gabrielson KL, Janssens S, Crijns HJ and Moens AL: DOX-induced cardiomyopathy: From molecular mechanisms to therapeutic strategies. J Mol Cell Cardiol 52: $1213-1225,2012$ 